\title{
КОНЦЕПТУАЛЬНІ ЗАСАДИ ПСИХОЛОГІЧНОї ДОПОМОГИ МОЛОДШИМ ШКОЛЯРАМ І3 ПОРУШЕННЯМИ ЗОРУ ТА ЇХ НАЙБЛИЖЧОМУ СОЦІАЛЬНОМУ ОТОЧЕННЮ
}

Вадим Кобильченко, Інститут спеціальної педагогіки Національної академії педагогічних наук України, м. Київ, Україна; vadimvk@ukr.net

Доведено, що слабка фуннціональна готовність чи неготовність до школи, відсутність навчальної мотивації призводять у кінцевому результаті до того, що школа стає для дітей 3 порушеннями зору постійним джерелом стресу. Визначено, що психологічна допомога - це система заходів, спрямованих на пом'якшення дії подій, пережитих як «труднощі життя", а також вирішення особистісних та інших проблем людини або цілих груп (зокрема, родини) засобами практичної психології. Встановлено, що надання психологічної допомоги в психологічній парадигмі потребує переходу від класифікації, заснованій на феномені хвороби (медична парадигма), до власне психологічної класифрікації людських проблем. З'ясовано, що зміст психологічної допомоги полягає в забезпеченні емоційної, значеннєвої й екзистенціальної підтримки людині або співтовариству в складних ситуаціях, що виникають у ході особистісного й соціального буття.

Ключові слова: молодші школярі з порушеннями зору, психологічна допомога.

Вадим Кобыльченко, Институт специальной педагогики Национальной академии педагогических наук Украины, г. Киев, Украина

Концептуальные основы психологической помощи младшим школьникам с нарушениями зрения и их ближайшему социальному окружению

Доказано, что слабая функциональная готовность или неготовность к школе, отсутствие учебной мотивации приводят в конечном результате к тому, что школа становится для детей с нарушениями зрения постоянным источником стресса. Определено, что психологическая помощь - это система мероприятий, направленных на смягчение действия событий, пережитых как «трудности жизни», а также решение личностных и других проблем человека или целых групп (в частности, семьи) средствами практической психологии. Установлено, что предоставление психологической помощи в психологической парадигме требует перехода от классификации, основанной на феномене болезни (медицинская парадигма), к собственно психологической классификации человеческих проблем. Выяснено, что содержание психологической помощи заключается в обеспечении эмоциональной, смысловой и экзистенциальной поддержки человеку или сообществу в сложных ситуациях, которые возникают в ходе личностного и социального бытия.

Ключевые слова: младшие школьники с нарушениями зрения, психологическая помощь.

(c) Кобильченко В., 2018

«ОСОБЛИВА ДИТИНА: навчання і виховання», № 4, 2018 
Vadym Kobylchenko, Institute of Special Pedagogy The National Academy of Pedagogical Sciences of Ukraine, Kyiv, Ukraine.

Conceptual bases of psychological help to young schoolchildren with violations and their nearest social environment

It is proved that weak functional readiness or unavailability for school, lack of educational motivation leads in the end result to the fact that the school becomes a constant source of stress for children with visual impairments. It is determined that psychological assistance is a system of activities aimed at mitigating the events experienced as "difficulties of life", as well as solving the personal and other problems of a person or entire groups (in particular, the family) by means of practical psychology. It is established that the provision of psychological assistance in the psychological paradigm requires a transition from a classification based on the phenomenon of disease (medical paradigm) to the actual psychological classification of human problems. It was found that the content of psychological assistance is to provide emotional, semantic and existential support to a person or community in difficult situations that arise in the course of personal and social life.

Keywords: junior pupils with visual impairment, psychological help.

Постановка проблеми. Відомо, що навчальні перевантаження, невідповідність між зовнішніми вимогами і внутрішніми можливостями дитини, слабка функціональна готовність або навіть цілковита неготовність до школи, відсутність навчальної мотивації призводять у кінцевому результаті до того, що школа стає для дітей $з$ порушеннями зору постійним джерелом стресу. В особливій ситуації ризику перебувають молодші школярі, оскільки саме їм необхідно швидко адаптуватися до нових складних умов шккільного життя.

Психофізичні розлади, психотравми, ригідні форми інфантильної поведінки, невирішені проблеми дошкільного дитинства суттєво ускладнюють перебіг особистісного становлення на даному віковому етапі, зумовлюючи виникнення на цьому шляху різноманітних труднощів психологічного характеру. Невдачі самоствердження, самовираження, що нерідко супроводжують спілкування молодшого школяра з порушеним зором з соціальним мікросередовищем, можуть призводити до згортання стосунків із зовнішнім світом, самоізоляції, депресивних станів. Життєві події в очах таких учнів набувають характеру складної проблеми, яку вони не в змозі самостійно вирішити. Можливо, саме тому вони часто ховаються від проблем у світі фантазій та мрій, які є для них більш яскравими, аніж події їнього власного життя.

Така поведінка є, по своїй суті, дезадаптивною, оскільки вона виявляється у тривалому переживанні внутрішніх та зовнішніх конфліктів без досягнення більш-менш дійової когнітивної стратегії вирішення своїх життєвих проблем. Дезадаптивна поведінка веде не до переборення проблемної ситуації, а лише до іï ускладнення, поглиблення особистих труднощів. Такі учні сприймають світ людських стосунків як небезпечний і підсвідомо вдаються до різних механізмів психологічного захисту. Їм притаманна невисока само- 
оцінка, низька мотивація досягнень. Вони, як правило, мають екстернальний локус контролю, убачаючи в оточуючих винуватців їніх власних негараздів (Кобильченко, 2017).

Отже, вікові завдання розвитку залишаються невирішеними, розходження між бажаним і доступним провокує внутрішній, переважно самооціночний, конфлікт. Під тиском загрози втратити стабільність образу «Я», його цілісність, особистість обирає не конструктивні когнітивні стратегії подолання життєвих труднощів, а вдається до психологічного захисту, «консервуючи» у собі внутрішні та зовнішні конфлікти.

Мета статті - теоретичне обгрунтування та розроблення концептуальних засад психологічної допомоги молодшим учням 3 порушеннями зору та їх найближчому соціальному оточенню.

Виклад основного матеіралу дослідження. Психологічна дезадаптація в умовах дизонтогенезу, коли молодший учень має ті чи інші, вроджені чи набуті порушення зору, що значно ускладнюють його взаємодію з навколишнім світом, стає згодом ще більш загрозливою. Психофізичний дефект не тільки об'єктивно впливає на психосоціальний розвиток дитини, ускладнюючи їі безпосередню взаємодію з довкіллям, а стає тим психологічним (суб'єктивним) чинником, який провокує появу суто психологічних проблем, насамперед самооціночного характеру (Кобильченко, 2017).

Хочемо зазначити, що для особистісного благополуччя молодших учнів із порушеннями зору, їхнього повноцінного розвитку й соціальної адаптації психологові необхідно проводити систематичну роботу, суть якої полягає у наданні своєчасної й адекватної віковим та індивідуальним можливостям дитини психологічної допомоги.

Під психологічною допомогою дитині з боку дорослого ми розуміємо такі загальні дії, у результаті яких із дитиною відбуваються якісні позитивні зміни: поліпшується іï самопочуття, формуються й успішно розвиваються корисні навички й уміння, вирішуються особистісні проблеми й наступає емоційне полегшення.

Під відсутністю психологічної допомоги дитині з боку дорослої людини (чи він психолог, педагог, батько або мати) переважно розуміється «несумісність» дій дорослого й дитини. 3 одного боку, вона може проявлятися як психологічний гніт (позиція «зверху»), а 3 іншого боку - як маніпулятивне пристосування до потреб, бажань, капризів дитини (позиція «знизу»). Немає жодної допомоги дитині від дорослого й тоді, коли він просто вникає неформальних контактів з нею, а разом із тим - і відповідальності за психологічні події у житті дитини.

Як сама психологічна допомога, так і іï відсутність у житті дитини проявляє себе у вигляді почуттів і переживань, думок, дій та вчинків. Все це разом, зазвичай, називають відносинами, або краще - взаєминами, які грунтуються на певних поведінкових установках. Дуже важлива в цьому контексті емпатія, яка забезпечує співпереживання, входження в емоційний стан іншої людини (у нашому випадку - дитини). Дорослий повинен, насамперед, стати дитині старшим товаришем, здобути іiі довіру.

«ОСОБЛИВА ДИТИНА: навчання і виховання», № 4, 2018 
Отже, діюєвою психологічною допомогою є тільки такий вплив дорослого на дитину, що здійснюється в умовах загальних позитивних взаємин.

Будь-яку взаємодію з іншою людиною можна розглядати: як фізичну дію дав, взяв, торкнувся, подивився і т. д.; як розумову дію - пояснив, навів приклад, поінформував тощо; як психологічну дію - заспокоїв, порадував, зневажив, не помітив тощо.

Причому, психологічна дія будується особливим чином. У своїй основі вона містить розумову дію, а виявляе себе - як фізична. Завдання іншої людини - зрозуміти психологічний зміст, грунтуючись тільки на фізичних діях, поведінкових проявах, які спостерігаються ззовні. Це дуже непросто, а дитині - тим більше.

Отже, саме шкільний психолог є тією людиною, яка може допомогти дитині з порушеним зором віднайти своє справжнє «Я», переглянути власну самооцінку, успішно вирішити свої особистісні та міжособистісні проблеми. Молодший учень не повинен залишатись наодинці із собою, в ізоляції від соціального довкілля. Тільки спілкуючись 3 іншими людьми, які мають схожі проблеми, він може переглянути свою систему оцінних ставлень щодо власного «Я» та значущих інших. Тактовне доброзичливе спілкування психолога 3 дитиною здатне забезпечити іiі духовне зростання, збагачення індивідуального досвіду тощо (Кобильченко, 2017).

Сучасне уявлення про психологічну допомогу дитині визначається, передусім, iї потребами. Основна мета - допомогти дитині, що опинилася у складній життєвій ситуації, забезпечити їй психологічний комфорт у ставленні до самої себе, а також у взаємодіях з іншими людьми і у відносинах до світу загалом.

Нині існує чимало різних думок на психологічну допомогу та ï визначень.

У «Дефектологічному словнику» за редакцією В. Бондаря та В. Синьова (2011) психологічна допомога визначається як галузь практичного застосування психології, спрямована на підвищення соціально-психологічної компетентності людей та надання допомоги окремим особам чи групам (сім'ям, трудовим колективам тощо) у розв'язанні проблем психологічного змісту: подолання внутрішніх, особистих і міжособистісних конфліктів.

Схожим є визначення у «Психологічному словнику» за загальною редакцією А. Петровського та М. Ярошевського (1990). Психологічна допомога визначена як царина практичного застосування психології, орієнтована на підвищення соціально-психологічної компетентності людей і надання психологічної допомоги як окремій людині, так і групі, організації. Це безпосередня робота з людьми, спрямована на вирішення різного роду психологічних проблем, пов’язаних із труднощами в міжособистісних відносинах, а також глибинних особистісних проблем.

Більш детально розкриває сутність поняття «психологічна допомога О. Бондаренко (2001). Він вважає, що поняття «психологічна допомога» відображає певну реальність, певну психосоціальну практику, полем діяльності якої є сукупність питань, утруднень і проблем, що належать до психічного життя людини. 
Уже таке, попереднє, хоча й очевидне, міркування потребує, на думку автора, уточнення границь понять «психіка», «психічне». I тут критерієм може послужити широко поширене в останні десятиліття у психології уявлення про людину як про єдність трьох рівнів: фізичного (body), психоемоційного (mind) $i$ духовного (spirit). Навіть таке схематичне членування розуміння людини досить виразно вказує на сферу діяльності, що позначається словосполученням «психологічна допомога». Очевидно, що цариною діяльності відповідного фахівця є широке коло проблем, у яких віддзеркалюються особливості психічного життя людини як соціальної істоти, так само як і особливості співтовариства, у яких відображається психологічна специфіка його функціонування (Бондаренко, 2001).

Отже, запевняє О. Бондаренко, логічно виходити з такого розуміння психологічної допомоги: це психологічна царина й спосіб діяльності, призначені для сприяння людині й співтовариству у вирішенні різноманітних проблем, породжуваних психічним життям людини в соціумі.

Розуміння проблематики психологічної допомоги пов'язане із розумінням психіки як такого простору (рівня, способу) людського буття, різноманіття i багатогранність якого й визначає сукупність проблем у діяльності відповідного фахівця: міжособистісні відносини, емоційні внутрішньоособистісні (як глибинні, так і ситуативні) конфлікти й переживання; проблеми соціалізації (вибір професії, створення родини, тощо), проблеми персоналізації (вікові й екзистенціальні), тобто весь спектр емоційно-значеннєвого життя людини як суспільної істоти, наділеної психікою.

У більш локальному сенсі, психологічна допомога - це система заходів, спрямованих на пом'якшення дії подій, пережитих як «труднощі життя», а також вирішення особистісних та інших проблем людини або цілих груп (наприклад, родини) засобами практичної психології. Метою таких заходів є психологічне здоров'я особистості, його відновлення й підтримка.

У поняття «психологічне здоров'я» входить гармонійна (рівноважна) взаємодія усіх сфер особистості: емоційної, вольової, пізнавальної. Саме критерій психічної рівноваги пов'язаний із цілісним розвитком особистості, $з$ іiі адаптивними можливостями й поняттям «психологічне здоров'я» (Шувалов, 2009).

На думку 3. Гришанової і О. Левченко (2002), показниками психологічного здоров'я особистості є: прийняття відповідальності за своє життя; саморозуміння і прийняття себе; уміння жити в теперішньому часі; свідомість індивідуального буття; здатність до розуміння та прийняття інших.

Водночас, психологічна допомога - це ємке поняття, зміст якого містить у собі різноманіття теорій і практик, що варіюються від специфічного застосування такого методу, як глибинне інтерв’ю, до різноманітних технік соціально-психологічного тренінгу, понять і методів медичної психотерапії, без яких відносини психолога-консультанта і його клієнта можуть легко зруйнуватися, а сама психологічна допомога - перетворитися на просте вираження співчуття або моралізування.

«ОСОБЛИВА ДИТИНА: навчання і виховання», № 4, 2018 
Відповідно до вищезазначених семантичних значень поняття «психологічна допомога» доцільно виділити кілька предметних перспектив, домінант, які створюють ефект панорамного бачення такого складного психосоціального простору, яким є психологічна практика:

1) особистість клієнта. Це передусім завдання, що належать до розвитку суб'єктності, до розвитку екзистенціальних (рефлексивних) і функціональних (інструментальних) основ особистісного «Я»: самовизначення (ідентичності), вибору (ухвалення рішення), самоусвідомлення (особистісної рефлексіі); поведінка у критичних (кризових) ситуаціях тощо;

2) стосунки з клієнтом. Процес надання психологічної допомоги передбачає певні самостійні завдання, що забезпечують позитивний потенціал усього процесу: встановлення відносин довіри й прийняття; забезпечення належної динаміки робочих стосунків, що веде до усвідомлення й можливого вирішення психологічних проблем клієнта; оброблення або, навпаки, зняття психологічних захистів; визначення й використання ступеня впливу на клієнта (від мінімальної простої емпатії, до максимальної). Самостійними завданнями стають визначення форм і технік ведення початкового інтерв'ю, термінів спільної роботи й способів завершення психологічної допомоги;

3) психологічна допомога співтовариству - колективу класу, школи, родині та ін. Основні й можливі завдання: адекватне орієнтування в ситуації, ідентифікація і локалізація (при необхідності) конфлікту; зняття соціально-психологічної напруженості, допомога у ціннісно-смисловій переорієнтації групи; підвищення (за необхідності) згуртованості й допомога у визначенні лідера й т. д;

4) завдання, що постають перед професіоналом, - це завдання, які стосуються вже не безпосередньо процесу психологічної допомоги, але, ті, що визначають їі доцільність і дієвість: завдання, що висуваються до його (професіонала) власного особистісного розвитку й благополуччя, до його професійної майстерності. Недостатня працьованість особистісних проблем (фрустрованих або нереалістичних потреб, фантазій, страхів, конфліктів, захистів, самооцінок, мотивів) i недостатня професійна (теоретична й технічна) підготовка можуть замість психологічної допомоги травмувати як клієнта, так і психолога, й додати до невирішених проблем ще й психогенні розлади.

3-поміж найбільш важливих етичних принципів психологічної допомоги Ю. Альошина (2000) виділяє такі:

- доброзичливе й безочінне ставлення до клієнта, що має на увазі цілий комплекс професійного поводження, спрямованого на те, щоб клієнт почував себе спокійно й комфортно. Консультантові необхідно вміти уважно слухати клієнта (наприклад, використовуючи техніку активного слухання), намагаючись зрозуміти його, не засуджуючи при цьому, а також надавати психологічну підтримку й допомогу;

- орієнтація психолога на норми й цінності клієнта, а не на соціально прийняті норми та правила, що дасть змогу клієнтові бути щирим і відкритим. Відносини прийняття цінностей клієнта і іхня повага є не тільки можливістю виразити підтримку клієнтові, а також дасть можливість уплинути в майбут- 
ньому на ці цінності, якщо вони стануть розглядатися в процесі консультування як перешкода для нормальної життєдіяльності людини;

- заборона давати поради. Психолог, навіть не зважаючи на свій професійний і життєвий досвід і знання, не може дати гарантовану пораду клієнтові, зокрема й тому, що життя клієнта й контекст його протікання унікальні та непередбачувані, і клієнт є основним експертом у своєму власному житті, у той час як психолог виступає як експерт в інших питаннях, зокрема в способах вибудовування відносин із клієнтом, а також у теорії й практиці психологічної допомоги. Крім того, дати пораду - значить прийняти на себе відповідальність за життя клієнта у випадку, якщо він нею скористається, що не сприяє розвитку його особистості. Крім того, даючи пораду, професійна позиція психолога може змінюватися, а приймаючи пораду, у клієнта може змінитися його позиція у бік більшої пасивності й поверхневого ставлення до того, що відбувається. Часто, при цьому, будь-які невдачі в реалізації порад клієнтом можуть приписуватися психологові, його авторитету, що заважає розумінню клієнтом своєї активної й відповідальної ролі в подіях, що відбуваються із ним;

- анонімність. Це означає, що ніяка інформація, повідомлена клієнтом психологові, не може бути передана без його згоди ні в які організації й іншим особам, а також родичам або друзям. Проте, існують винятки (про які психолог повинен заздалегідь попереджати клієнта), спеціально визначені в законодавстві;

- розмежування особистих і професійних відносин - цей принцип-вимога до консультанта, пов'язаний з низкою психологічних феноменів, що впливають на процес психологічної допомоги. Наприклад, відомо, що на професійні стосунки можуть мати сильний вплив відносини особисті, зокрема особисті потреби й бажання психолога впливають як на процес психологічної допомоги, так і на самого клієнта, а отже, можуть перешкоджати ефективному здійсненню психологічної допомоги. $\mathrm{C} \mathrm{різні} \mathrm{дослідження} \mathrm{цих} \mathrm{впливів} \mathrm{(наприклад,} \mathrm{фено-}$ мени переносу й контрпереносу).

Висновки. Насамкінець зазначимо, що надання психологічної допомоги в психологічній парадигмі потребує переходу від класифікації, заснованій на феномені хвороби (медична парадигма), до власне психологічної класифікації людських проблем.

Зміст психологічної допомоги полягає в забезпеченні емоційної, значеннєвої й екзистенціальної підтримки людині або співтовариству в складних ситуаціях, що виникають у процесі особистісного й соціального буття. Психологічна допомога може містити в собі: психодіагностику (повідомлення клієнтові об'єктивної психологічної інформації, відповідальність за вірогідність і форму повідомлення несе психолог), психологічну корекцію (цілеспрямований вплив на клієнта з метою зміни показників його активності у відповідності з віковою нормою психічного розвитку; розробляється індивідуальна програма), психологічне консультування (допомога психічно здоровим людям у досягненні ними цілей особистісного розвитку).

Отже, основними напрямами роботи психолога в початковій школі мають бути: діагностична; корекційно-розвивальна та консультативно-просвітницька робота.

«ОСОБЛИВА ДИТИНА: навчання і виховання», № 4, 2018 


\section{ЛITEPATУPA}

1. Алешина Ю. Е. Индивидуальное и семейное психологическое консультирование / Ю. Е. Алешина. - 2-е изд. - М.: Независимая фирма «Класс», 2000. - 208 с.

2. Бондаренко А. Ф. Психологическая помощь: теория и практика / А. Ф. Бондаренко. Изд. 3-е, испр. и доп. - М. : Независимая фирма «Класс», 2001. - 336 с.

3. Гришанова 3. И. К вопросу о диагностике психического здоровья личности / З. И. Гришанова, Е. В. Левченко // Прикладная психология. - 2002. - № 2. - С. 90-96.

4. Дефектологічний словник: навч. посіб. / За ред. В. І. Бондаря, В. М. Синьова. - К. : «МП Леся», 2011. - 528 c.

5. Кобильченко B. B. Теоретичні основи психолого-педагогічного супроводу молодших школярів з порушеннями зору / В.В. Кобильченко; Інститут спеціальної педагогіки НАПН України. - Полтава: ТОВ «Фірма «Техсервіс», 2017. - 367 с.

6. Психологический словарь / Под общ. ред. А. В. Петровского, М. Г. Ярошевского. - 2-е изд., испр. и доп. - М. : Политиздат, 1990. - 494 с.

7. Шувалов А. В. Психологическое здоровье человека / А. В. Шувалов // Вестник ПСТГУ IV: Педагогика. Психология, 2009. - Вып. 4 (15). - С. 87-101.

\section{REFERENCES (TRANSLATED AND TRANSLITERATED)}

1. Aleshina Ju. E. (2000). Individual'noe i semejnoe psihologicheskoe konsul'tirovanie. Moskva: Nezavisimaja firma «Klass». [In Russian].

2. Bondarenko A.F.(2001). Psihologicheskaja pomoshh': teorija i praktika. Moskva:Nezavisimaja firma «Klass». [In Russian].

3. Grishanova Z. I., Levchenko, E. V. (2002). K voprosu o diagnostike psihicheskogo zdorov'ja lichnosti. Prikladnaja psihologija. 2. - pp. 90-96. [In Russian].

4. Defektolohichnyi slovnyk: navch. posib. (2011). Kyiv: «MP Lesia». [In Ukrainian].

5. Kobylchenko V. V. (2017). Teoretychni osnovy psykholoho-pedahohichnoho suprovodu molodshykh shkoliariv z porushenniamy zoru. Poltava: TOV «Firma «Tekhservis». [In Ukrainian].

6. Psihologicheskij slovar' (1990). Moskva: Politizdat. [In Russian].

7. Shuvalov A. V. (2000). Psihologicheskoe zdorov'e cheloveka. Vestnik PSTGU IV: Pedagogika. Psihologija. 4 (15). - pp. 87-101. [In Russian]. 